\title{
The Climate Change Dimension of Business and Human Rights: The Gradual Consolidation of a Concept of 'Climate Due Diligence'
}

\author{
Chiara MACCHIT $\left.\right|^{*}$
}

\begin{abstract}
This article makes the case for a 'holistic' approach to human rights due diligence, arguing that such a standard must be interpreted in the light of mutually reinforcing principles of environmental law, climate law and human rights law. Through a review of emerging climate change-related litigation, it shows how a concept of 'climate due diligence' is gradually consolidating. Building on the United Nations Guiding Principles on Business and Human Rights, the article explores climate due diligence both as a standard of conduct and as a business process, presenting its main features. It argues that corporations should integrate climate due diligence into their processes and policies to be best prepared for likely regulatory and judicial developments, such as the upcoming European Union's regulation on human rights and environmental due diligence.
\end{abstract}

Keywords: Climate change, Corporate liability, Due diligence, Environment, European Union

\section{INTRODUCTION}

The last decade has witnessed a consolidating consensus in the international community about the need to treat climate change and its consequences as a human rights issue. ${ }^{1}$ As underlined in 2015 by John H Knox, the former UN Special Rapporteur on human rights and the environment, human rights obligations relating to the environment duties of States to adopt legal and institutional frameworks that protect against environmental harm that interferes with the enjoyment of human rights, including harm caused by private

II Conflicts of interest: The author declares none.

* Chiara Macchi is a Marie Skłodowska-Curie Postdoctoral Researcher, Law Group, Wageningen University, Netherlands. The author is leading the research project 'The EU as a Leading Global Actor in Business and Human Rights: Towards a Coherent Policy Framework'. The publication of this article has been supporetd by funding from the European Union's Horizon 2020 research and innovation programme under the Marie Skłodowska-Curie grant agreement no. 843115-BHR_EU.

1 Michael Burger and Jessica Wentz, Climate Change and Human Rights (Nairobi: UNEP, 2015) 11; 'Paris Agreement: Preamble', https://unfccc.int/sites/default/files/english_paris_agreement.pdf (accessed 26 October 2020). 
actors'. ${ }^{2}$ Preventing and redressing the human rights harm deriving from manmade climate change arguably also falls under both the 'state duty to protect' (Pillar I) and the 'business responsibility to respect' (Pillar II) articulated by the United Nations Guiding Principles on Business and Human Rights (UNGPs). Current policy and judicial developments show that a 'climate due diligence' is increasingly taking shape as a dimension of the human rights due diligence (HRDD) obligations of both states and corporations. The number of climate change-related lawsuits, while still relatively low and uncertain as to the outcomes, is growing, and is taking new and creative legal avenues. At the same time, in addition to HRDD legislation already adopted by some countries, the European Union (EU) is considering the adoption of legislation establishing human rights and environmental due diligence obligations for corporations. These developments provide unprecedented opportunities to clarify the specific obligations of public and private actors in relation to anthropogenic climate change and its human rights impacts.

This article begins in section II with an up-to-date picture of the current state of climate change-related litigation, with special focus on the European context. The analysed cases illustrate the emerging features of a 'climate due diligence' of corporations. It is argued that corporations should start integrating the climate change dimension into their processes and policies to be best prepared for likely regulatory and judicial developments. Section III makes the case for a 'holistic' approach to HRDD as defined in the UNGPs, arguing that the relevant standard of conduct must be interpreted in the light of mutually reinforcing principles of environmental law, climate law and human rights law. The concept of climate due diligence is explored both as a standard of conduct and as a business process. Section IV presents some concluding thoughts.

\section{Climate Change Litigation and the Emergence of A 'Climate Due Diligence'}

This section reviews a series of climate change-related cases, filed either in the $\mathrm{EU}^{3}$ or abroad, which can potentially add pieces to the developing definition of a corporate climate due diligence as a dimension of HRDD. The selected pool of cases was drawn from the Sabin Center's database ${ }^{4}$ and integrated with some relevant complaints filed with Organisation for Economic Co-operation and Development (OECD) National Contact Points (NCPs). This selection of cases includes most of those that have been filed by individuals, groups or non-governmental organizations (NGOs) against corporations, EU institutions and governments. Significantly, although older examples exist, it appears that the majority of relevant cases have been filed between 2013 and

\footnotetext{
2 John H Knox, 'Report of the Independent Expert on the issue of human rights obligations relating to the enjoyment of a safe, clean, healthy and sustainable environment', A/HRC/28/61 (3 February 2015), para 2.

3 For the purpose of this article, the UK is also considered among the EU member states, as the referenced cases were initiated prior to Brexit finalization.

4 Sabin Center for Climate Change Law, 'Climate Change Litigation Databases', http://climatecasechart.com/ (accessed 27 October 2020).
} 
2019, confirming the climate change litigation in the European region as a recent phenomenon. While the trend is growing, ${ }^{5}$ the numbers in the European continent are still relatively low. At the time of writing, a total of 91 cases have been filed in $12 \mathrm{EU}$ member states. ${ }^{6}$ However, in line with the global trend, ${ }^{7}$ a relative majority (47 per cent) of the court cases filed in EU member states were initiated by corporations against public bodies, ${ }^{8}$ typically to challenge individual assignment of emissions allowances or the denial of a licence based on environmental considerations. ${ }^{9}$ The importance of climate change litigation, both at the global level and in the European continent, therefore, does not lie in the absolute numbers, but has more to do with the possible outcomes of strategic litigation, including against corporations, and with an increasingly frequent resort to human rights arguments. ${ }^{10}$

This section primarily deals with cases promoted against corporations with the aim of showing how judicial and non-judicial bodies, besides holding corporations accountable, may contribute to defining the standard of due diligence required of businesses in relation to climate change. In addition, it reviews some cases aimed at challenging the relevant policies of public bodies. While not directly concerning the accountability of private actors, these lawsuits contribute to identifying the main tenets of an emerging climate due diligence and may prompt new regulation of business activities contributing to greenhouse gas $(\mathrm{GHG})$ emissions. ${ }^{11}$

\section{A. Strategic Litigation Against Corporations}

\section{Lawsuits Drawing the Link Between Climate Change and Human Rights Due Diligence}

At present only a limited number of lawsuits directly targeting the climate change impacts of corporations, and an even narrower sample with an explicit human rights dimension, exist. As an example of the latter, in April 2019, Milieudefensie and other NGOs submitted a court summons against Royal Dutch Shell alleging the corporation's violation of its duty of care anchored in Dutch law, human rights law and the Paris

\footnotetext{
5 Michal Nachmany and Joana Setzer, 'Policy Brief - Global Trends in Climate Change Legislation and Litigation: 2018 Snapshot' (2018) 5, https://www.lse.ac.uk/GranthamInstitute/wp-content/uploads/2018/04/Global-trends-inclimate-change-legislation-and-litigation-2018-snapshot-3.pdf (accessed 26 October 2020).

6 The countries are: Austria, Belgium, Czech Republic, France, Germany, Ireland, Luxembourg, Netherlands, Poland, Spain, Sweden and the UK. Looking at the broader group of the Council of Europe's member states, relevant lawsuits have also been filed in Norway, Switzerland and Ukraine. Sabin Center for Climate Change Law, 'Non-U.S. Jurisdiction', http://climatecasechart.com/non-us-jurisdiction/ (accessed 26 October 2020).

7 Nachmany and Setzer, note 5, 5.

8 Thirty-eight cases out of 84, concentrated in the UK (22 out of 47), Spain (13 out of 13) and France (3 out of 5) (elaboration based on the database of the Sabin Center for Climate Change Law, note 4).

9 See, for instance, Sabin Center for Climate Change Law, 'Spain', http://climatecasechart.com/non-us-jurisdiction/ spain/; 'Bradford v. West Devon Borough Council', http://climatecasechart.com/non-us-case/bradford-v-west-devonbc/; 're Emission Quotas: Decision No. 2010-622 DC of December 28, 2010', http://climatecasechart.com/non-us-case/ re-emission-quotas-decision-no-2010-622-dc-of-dec-28-2010/ (accessed 27 October 2020).

10 Nachmany and Setzer, note 5, 7; Jaqueline Peel and Hari M Osofsky, 'A Rights Turn in Climate Change Litigation?' (2018) 7:1 Transnational Environmental Law 37, 40.

11 Nachmany and Setzer, note 5, 7.
} 
Agreement. ${ }^{12}$ This approach proposes an integrated interpretation of corporate HRDD based on both human rights law and climate law standards. ${ }^{13}$ The plaintiffs clearly aim at riding the long wave of the Urgenda judgment (see section II.B below) and extending its conclusions, mutatis mutandis, to private actors. ${ }^{14}$ The allegations against Shell include its insufficient action to reduce GHG emissions and the active attempt to mislead the public about the sustainability of its operations. ${ }^{15}$ The summons reference the main business and human rights instruments, including the UNGPs (publicly endorsed by Shell), to argue that climate change impacts must be accounted for in the HRDD processes of corporations, which also have a responsibility not 'to undermine the ability of States to fulfil their own human rights obligations'. ${ }^{16}$ The summons refer to the Dutch law social standard of care successfully invoked in Urgenda to argue that 'Articles 2 and 8 of the ECHR also colour the duty of care we should be able to expect from Shell', given 'the extent of the control Shell - like the State - has over [the fate of] individuals on account of its substantial share in global emissions and the solutions to climate change.' ${ }^{17}$ The plaintiffs maintain that Shell has a duty to adjust its policies and practices to the Paris Agreement targets with due regard to the precautionary principle. ${ }^{18}$

In early 2020, an action against Total under the French Duty of Vigilance Law was filed in France by fourteen French cities and four NGOs. ${ }^{19}$ This Law requires corporations to put in place and implement a 'vigilance plan' to address human rights and fundamental freedoms risks, severe physical or environmental harms or health risks. ${ }^{20}$ For the first time, a lawsuit was filed under the Duty of Vigilance Law to target the 'climate inaction' of an oil corporation. ${ }^{21}$ The plaintiffs, representatives of local communities and organizations, hold that identifying the risk of contributing to global warming and taking measures to reduce emissions is an integral part of the corporation's 'duty of vigilance'. ${ }^{22}$ Total was targeted as one of the world's bigger emitters, being responsible for 1 per cent of the world's total GHG emissions and for two-thirds of France's emissions. ${ }^{23}$ The corporation is accused of failing to include concrete climate-related

\footnotetext{
12 Milieudefensie et al v Royal Dutch Shell plc, File no. 90046903, Summons (5 April 2019), http:// blogs2.law.columbia.edu/climate-change-litigation/wp-content/uploads/sites/16/non-us-case-documents/2019/20190405_ 8918_summons.pdf (accessed 27 October 2020).

13 This aspect is discussed in section III.

14 Sabin Center for Climate Change Law, 'Milieudefensie et al v Royal Dutch Shell plc', http://climatecasechart.com/ non-us-case/milieudefensie-et-al-v-royal-dutch-shell-plc/ (accessed 17 December 2019).

15 Milieudefensie et al, note 12.

16 Ibid, para 712.

17 Ibid, paras 723-724.

18 Ibid, para 55.

19 Aline Robert, 'Oil Giant Total Sued For 'Climate Inaction' in France's First Climate Case', Euractiv (28 January 2020), https://www.euractiv.com/section/climate-environment/news/oil-giant-total-sued-for-climate-inaction-in-francesfirst-climate-case/ (accessed 20 May 2020).

20 Stéphane Brabant, Charlotte Michon and Elsa Savourey, 'The Vigilance Plan: Cornerstone of the Law on the Corporate Duty of Vigilance' (2017) 5 Revue Internationale de la Compliance et de l'Éthique des Affaires 6, http:// www.bhrinlaw.org/frenchcorporatedutylaw_articles.pdf (accessed 20 May 2020).

21 Robert, note 19.

22 Ibid.

23 Ibid; BHRCC, 'Total Lawsuit (re Climate Change, France)', https://www.business-humanrights.org/en/totallawsuit-re-climate-change-france-0 (accessed 20 May 2020).
} 
objectives in both its first and second vigilance plan. Instead of taking the required steps towards the $2{ }^{\circ} \mathrm{C}$ goal established by the Paris Agreement, ${ }^{24}$ the corporation allegedly increased its oil production and continues to invest in exploration for new oil deposits. ${ }^{25}$ While the lawsuit is in its initial phase, it shows how the open-ended duty of vigilance contained in the French Duty of Vigilance Law potentially allows for an integrated interpretation of the corporate duty of care informed by a variety of international human rights, environmental and climate standards.

The climate change responsibilities of 47 'Carbon Majors' - including some European corporations such as BP, Shell, Total, RWE, Repsol, LaFarge, Heidelberg Cement and Eni $^{26}$ - were notoriously raised in a petition filed with the Philippines Commission on Human Rights by Greenpeace Southeast Asia and a number of organizations and individuals. ${ }^{27}$ The petitioners asked the Commission to investigate the human rights impacts of climate change in the Philippines and the responsibility of 'investor-owned Carbon Majors for human rights threats and/or violations in the Philippines, resulting from climate change and ocean acidification'. ${ }^{28}$ The petition builds on studies that trace anthropogenic GHG emissions to specific corporations, ${ }^{29}$ and largely relies on the UNGPs. Referring to HRDD, it argues that, by taking investment decisions incompatible with the $2{ }^{\circ} \mathrm{C}$ goal, the corporations are 'failing to prevent human rights impacts that are directly linked to their operations, products, or services' by their business relationships. ${ }^{30} \mathrm{~A}$ joint summary of amicus curiae briefs also stresses that corporations, under the UNGPs, are responsible for assessing and addressing the climate change impacts of their operations, which translates into a responsibility to reduce their GHG emissions, at a minimum, in line with the temperature goals of the Paris Agreement. ${ }^{31}$ It also stresses how the carbon producers have long known of the adverse impacts of their operations but failed to act upon such knowledge, and even actively misrepresented the connection between fossil fuels and climate change. ${ }^{32}$

\footnotetext{
24 Sherpa et al, 'Statement of Claim Against Total' (28 January 2020), 2, https://www.business-humanrights.org/sites/ default/files/Dossier\%20de\%20presse\%20\%5BEN\%5D.pdf (accessed 4 May 2020).

25 Sherpa et al, '13 French Local Authorities and 4 NGOs Ask the French Oil Company Total to Prevent Global Warming' (23 October 2018), https://notreaffaireatous.org/wp-content/uploads/2018/10/Dossier-de-Press-2F-Englishversion.pdf (accessed 4 December 2019).

26 For the full list of respondents, see Greenpeace Southeast Asia et al, 'Petition - Requesting for Investigation of the Responsibility of the Carbon Majors for Human Rights Violations or Threats of Violations Resulting from the Impacts of Climate Change', Annex C (2015), https://storage.googleapis.com/planet4-philippines-stateless/2019/05/4879ea584879ea58-annex_c_list_of_respondents_with_addresses.pdf (accessed 4 May 2020).

27 Greenpeace Southeast Asia et al, 'Petition - Requesting for Investigation of the Responsibility of the Carbon Majors for Human Rights Violations or Threats of Violations Resulting from the Impacts of Climate Change' (2015), https:// storage.googleapis.com/planet4-philippines-stateless/2019/05/5a38951a-5a38951a-cc-hr-petition_public-version.pdf (accessed 4 May 2020).

28 Ibid, 61.

29 Richard Heede, 'Tracing Anthropogenic Carbon Dioxide and Methane Emissions to Fossil Fuel and Cement Producers, 1854-2010' (2014) 122 Climatic Change 229; Peter C Frumhoff, Richard Heede and Naomi Oreskes, 'The Climate Responsibilities of Industrial Carbon Producers' (2015) 132 Climatic Change 157.

30 Greenpeace Southeast Asia et al, note 27, 21-22.

31 'Joint Summary of the Amicus Curiae in Re: National Inquiry on the Impact of Climate Change on the Human Rights of the Filipino People' (2018), 59, https://climate.law.columbia.edu/sites/default/files/content/docs/Joint-SummaryAmicus_0.pdf (accessed 4 May 2020).

32 Ibid.
} 
In December 2019, at COP25, the Commission on Human Rights announced its findings (unpublished at the time of writing), stating that the carbon majors can be held liable for their contribution to climate change and that access to justice must be ensured for victims of the related human rights impacts. ${ }^{33}$ The statement also specified that criminal liability might arise 'where they have been clearly proved to have engaged in acts of obstruction and willful obfuscation'. ${ }^{34}$ Although the Commission does not have strong coercive and enforcement powers, its final findings might shed a light on the link between climate due diligence and HRDD, and could be taken into account in the elaboration of new regulatory instruments, as well as in future litigation. ${ }^{35}$

\section{Emerging Features of the 'Climate Due Diligence' of Corporations: Risk Mitigation and Integration}

None of the cases noted above has reached its final stage yet. However, the legal reasonings adopted by their proponents highlight some possible features of an emerging concept of 'climate due diligence'. These tend to revolve around two main themes, namely, 'risk mitigation' on the one hand, and 'integration' on the other. While the former is concerned with the reduction of GHG emissions in corporations' activities and projects, the latter requires corporations to integrate climate-related objectives in their policies and processes.

A rather clear indication that can be extrapolated from existing cases concerns the risk mitigation responsibilities of the so-called 'big emitters'. As the corporations targeted in the examples discussed above are connected to major amounts of emissions, the proponents argue that a necessary step in their due diligence process is to commit to and carry out a significant reduction of the GHG emissions directly produced or 'linked to' the corporations' operations by their investments. All these cases rely on climate science and the Paris Agreement as benchmarks against which the adequacy of a corporation's action should be assessed. The argument that big emitters bear a specific responsibility for the adverse impacts caused by climate change also emerges from a 2015 German lawsuit that does not explicitly reference the concept of HRDD. The lawsuit, which targets the German utility RWE, ${ }^{36}$ rests on a provision of the German Civil Code on nuisance abatement. ${ }^{37}$ The promoter of the case ${ }^{38}$ is a Peruvian farmer whose town is

\footnotetext{
33 Greenpeace Philippines, 'The Climate Change and Human Rights Petition' (9 December 2019), https:// www.greenpeace.org/philippines/press/1237/the-climate-change-and-human-rights-petition/ (accessed 21 May 2020).

34 Isabella Kaminski, 'Carbon Majors can be Held Liable for Human Rights Violations, Philippines Commission Rules', Climate Liability News (9 December 2019), https:/www.climateliabilitynews.org/2019/12/09/philippineshuman-rights-climate-change-2/ (accessed 21 May 2020).

35 Annalisa Savaresi and Jacques Hartmann, 'Using Human Rights Law to Address the Impacts of Climate Change: Early Reflections on the Carbon Majors Inquiry' (2 November 2018) 16, https://ssrn.com/abstract=3277568 (accessed 21 May 2020).

36 BHRRC, 'RWE Lawsuit: First Test Case in Europe to Clarify Responsibilities of Carbon Majors for Climate Change', https://www.business-humanrights.org/en/rwe-lawsuit-first-test-case-in-europe-to-clarify-responsibilities-ofcarbon-majors-for-climate-change (accessed 10 December 2019).

37 Ibid.

38 At the time of writing, the lawsuit is at the stage of evidence collection [Germanwatch, 'Saúl versus RWE - The Huaraz Case', https://germanwatch.org/en/huaraz (accessed 11 May 2020)].
} 
facing the costs of protecting its population from the adverse effects of melting glaciers. ${ }^{39}$ The exponential volume increase of a glacial lake located above the town is allegedly a product of climate change caused by global GHG emissions, to which RWE is the largest European contributor. ${ }^{40}$ The lawsuit alleges that RWE has contributed nearly 0.5 per cent of global manmade emissions since the industrial revolution, therefore being liable to compensate the plaintiff, in the same portion, for the costs of protecting his town from floods or mudslides. ${ }^{41}$ After the first instance court dismissed the claim, the appeals court allowed the case to proceed to the evidentiary phase. ${ }^{42}$ The court will assess the threat to the defendant's property due to the expanding volume of water of the Palcacocha lagoon, as well as the extent of RWE's contribution to that risk. ${ }^{43}$ One of the case's legal counsels, Roda Verheyen, declared that one of the strategic goals of the lawsuit has already been achieved, namely establishing that 'climate damages could give rise to corporate liability'. ${ }^{44}$ The next challenges lie in proving that RWE's emissions contributed to an imminent risk faced by the plaintiff and in establishing the relevant standard of proof. ${ }^{45}$ The recent declaration of Vanuatu's foreign minister shows that, in the future, similar allegations might be made against corporations by the governments of countries that are particularly prone to the adverse effects of anthropogenic climate change. ${ }^{46}$

Big emitters are also the target of a lawsuit filed in San Francisco by a large US-based fishing association against oil and gas producers, including Europe-domiciled Shell, Eni, Total and BP. ${ }^{47}$ The activities of these corporations are put in a causal relationship with the global warming-induced algae blooms that are forcing the closure of crab-fishing waters in the Pacific, damaging the industry. ${ }^{48}$ The defendants are not only accused of negligence and nuisance, but also of having concealed the dangers for decades, working

\footnotetext{
39 Sabin Center for Climate Change Law, 'Lliuya v RWE AG, Case No. 2 O 285/15 Essen Regional Court', http:// climatecasechart.com/non-us-case/lliuya-v-rwe-ag/ (accessed 11 May 2020).

40 Christoph Bals and Roxana Baldrich, 'RWE Lawsuit: First Test Case in Europe to Clarify Responsibilities of Carbon Majors for Climate Change', Germanwatch (8 November 2018), https://germanwatch.org/en/15999 (accessed 11 May 2020).

41 Ibid.

42 Lliuya $v$ RWE AG, Case No. 2 O 285/15 (judgment of 30 November 2017), http://blogs2.law.columbia.edu/climatechange-litigation/wp-content/uploads/sites/16/non-us-case-documents/2017/20171211_Case-No.-2-O-28515-EssenRegional-Court_order-1.pdf (accessed 10 December 2019).

43 Ibid, 2-3.

44 Bals and Baldrich, note 40.

45 Ibid.

46 'My government is now exploring all avenues to utilize the judicial system in various jurisdictions - including under international law - to shift the costs of climate protection back onto the fossil fuel companies, the financial institutions and the governments that actively and knowingly created this existential threat to my country.' Lisa Cox, 'Vanuatu Says it May Sue Fossil Fuel Companies and Other Countries Over Climate Change', The Guardian (22 November 2018), https:// www.theguardian.com/world/2018/nov/22/vanuatu-says-it-may-sue-fossil-fuel-companies-and-other-countries-overclimate-change (accessed 17 December 2019).

47 Pacific Coast Federation of Fishermen's Associations, Inc v Chevron Corp (ND Cal) 3:18-cv-07477, Complaint (2018), http://blogs2.law.columbia.edu/climate-change-litigation/wp-content/uploads/sites/16/case-documents/2018/ 20181114_docket-CGC-18-571285_complaint.pdf (accessed 5 December 2019).

48 David Hasemyer, 'Crab Fishers Sue Fossil Fuel Industry Over Climate Change Damage', Inside Climate News (14 November 2018), https://insideclimatenews.org/news/14112018/crab-fishermen-climate-change-lawsuit-fossil-fuelcompanies-ocean-algae-neurotoxin-fishery-closure (accessed 17 December 2019).
} 
'to undermine public support for greenhouse gas regulation' ${ }^{49}$ Once again, albeit not framed in human rights terms, the lawsuit insists on the nexus between the contribution of big emitters to global warming and the resulting adverse impacts, as well as on their failure to honestly communicate to the public the climate-related risks of their activities.

Regarding the integration of the climate change dimension into business processes and policies, several of the cases discussed in section II.A.1 insist on the business responsibility to perform an adequate risk assessment and set concrete climate objectives, which are also key tenets of the HRDD concept articulated by the UNGPs. Those cases stress the responsibility of corporations to communicate externally their climate-related impacts and actions in an honest and accurate manner. Other clues to what integration means derive from at least two climate-related complaints that have been filed with the NCPs. It is worth recalling that the OECD Guidelines for Multinational Enterprises, besides a chapter on human rights reproducing the UNGPs' concept of HRDD, contain a separate chapter on Environment (chapter VI). ${ }^{50}$ Chapter VI requires corporations to perform an environmental due diligence process whose steps - risk assessment, establishment of measurable objectives, prevention based on the precautionary principle, mitigation actions, ongoing monitoring - closely recall the steps of HRDD. The OECD Guidelines specifically encourage corporations to disclose accurate information on GHG emissions ${ }^{51}$ and work towards their reduction. ${ }^{52}$ Honest and accurate communication of climate change impacts constitutes the main focus of a pending complaint filed against BP before the UK's NCP. ClientEarth's complaint alleges that a BP advertising campaign gravely misrepresents the corporation's efforts towards a transition to sustainable energy supply, while misleading consumers as to the seriousness of the climate change consequences that BP contributes to through its expanding fossil fuel business. ${ }^{53}$ The complaint does not reference chapter IV on 'Human Rights', but it alleges a breach of the Guidelines' chapters on Environment and Consumer Interests. ${ }^{54}$ In doing so, it highlights elements of environmental due diligence that the corporation allegedly failed to observe, namely the duty to provide accurate and verifiable information to the public on its potential environmental impacts. ${ }^{55}$

\footnotetext{
49 Pacific Coast Federation of Fishermen's Associations, Inc v Chevron Corp, note 47, para 7. On misleading climaterelated lobbying, see also BHRCC, 'InfluenceMap Report Alleges Misleading Climate-Related Branding and Lobbying by Major Oil and Gas Companies; BP, Chevron, ExxonMobil, Shell and Total Responded', https://www.businesshumanrights.org/en/influencemap-report-alleges-misleading-climate-related-branding-lobbying-by-major-oil-gascompanies-bp-chevron-exxonmobil-shell-total-responded (accessed 17 December 2019).

50 OECD Guidelines for Multinational Enterprises (2011). The OECD has also issued human rights due diligence guidance which includes reference to environmental impacts and provides indicators to assess their scope, scale and irremediable character (OECD, Due Diligence Guidance for Responsible Business Conduct (2018), http:// mneguidelines.oecd.org/OECD-Due-Diligence-Guidance-for-Responsible-Business-Conduct.pdf ～(accessed 27 October 2020).

51 OECD Guidelines, note 50, ch III.

52 Ibid, ch VI.

53 ClientEarth, 'Complaint Against BP in Respect of Violations of the OECD Guidelines' (2019), para 6, http:// blogs2.law.columbia.edu/climate-change-litigation/wp-content/uploads/sites/16/non-us-case-documents/2019/ 20191204_NA_complaint-1.pdf (accessed 17 May 2020).

54 Ibid.

55 Ibid, para 208
} 
Another NCP complaint calls into question the responsibilities of investors for being linked to the adverse impacts of climate change by their investment relationships. It was filed before the Dutch NCP by three NGOs alleging that ING bank's policies did not align with the climate and environment norms of the Guidelines. ${ }^{56}$ The NGOs requested the disclosure of the bank's GHG emissions and the establishment of concrete targets to progressively align ING's indirect GHG emissions with the objectives of the Paris Agreement. ${ }^{57}$ The NCP did not accept the bank's justification that there are not, at present, reliable data or international standards to measure the carbon emissions of a bank's lending portfolios. ${ }^{58}$ It stressed the financial institution's responsibility, even in the absence of internationally accepted methodologies, 'to seek measurement and disclosure of environmental impact in areas where reporting standards are still evolving', particularly in the case of GHG emissions. ${ }^{59}$ Commercial banks are thus required, under the OECD Guidelines, to take steps to define targets for the purpose of aligning their impact, as much as possible, 'with relevant national policies and international environmental commitments', such as the Paris Agreement. ${ }^{60}$

The cases (before both judicial and non-judicial bodies) presented in this section, albeit still embryonic, show some features of an emerging notion of climate due diligence requiring corporations to assess and address risk, as well as to integrate the climate change dimension into vigilance planning, corporate reporting, external communication and investment decisions. As the next section shows, these themes emerge as fundamental also in the currently available examples of litigation against public authorities.

\section{B. Climate Change Litigation Against Public Authorities and its Relevance for Businesses}

Climate change strategic litigation is finding a 'a novel and unique anchorage' in the Paris Agreement and in the related national commitments. ${ }^{61}$ The Paris Agreement implies two clear obligations on the part of states: (i) to prepare, communicate and maintain 'nationally determined contributions' (NDCs); and (ii) to ensure that each successive NDC will represent a progression beyond the previous one, reflecting the state's 'highest possible ambition'. ${ }^{62}$ The Agreement, therefore, staves off claims that an individual

\footnotetext{
56 Dutch NCP, 'Final Statement - Oxfam Novib, Greenpeace Netherlands, BankTrack and Friends of the Earth Netherlands (Milieudefensie) versus ING' (2019), 2, https://www.oecdguidelines.nl/documents/publication/2019/04/ 19/ncp-final-statement-4-ngos-vs-ing (accessed 27 October 2020).

57 Ibid.

58 Ibid.

59 Ibid, 5.

60 Ibid. The responsibility of investors is also being raised in a complaint filed with the Australian NCP by bushfire victims against ANZ Bank. At issue is the bank's continued investment in fossil fuel projects and its allegedly misleading communication to the public concerning its support of the Paris Agreement. Friends of the Earth Australia, 'Bushfire Survivors Launch Claim Against ANZ Under International Law for Financing Climate Change' (2019), https:// www.foe.org.au/bushfire_survivors_launch_claim_against_anz (accessed 10 September 2020).

61 UNEP, The Status of Climate Change Litigation - A Global Review (Nairobi: UNEP, 2017), https:// wedocs.unep.org/bitstream/handle/20.500.11822/20767/climate-change-litigation.pdf?sequence=1\&isAllowed=y (accessed 27 October 2020).

62 Paris Agreement, note 1, art 4.
} 
country's impact on climate change is too marginal to give rise to specific responsibilities, while prohibiting any retrogression in the ambitiousness of national mitigation and adaptation targets. ${ }^{63}$ Although not legally binding under international law, national commitments in the framework of the Paris Agreement can be resorted to in strategic litigation to define the state's due diligence obligations with respect to climate change. This type of litigation, which in some cases leverages the state's due diligence obligations under international human rights law, might have tangible consequences for businesses in that it has the potential to accelerate and inform policy developments such as the transition to a low-carbon economy or the regulation of certain types of business activities.

In the European context, the most notable example of this approach is currently represented by the lawsuit promoted by the Urgenda Foundation on behalf of 886 individuals against the government of the Netherlands. ${ }^{64}$ The lawsuit concerned the alleged inadequacy of the measures adopted by the country to reduce GHG emissions, and the plaintiffs claimed that the Netherlands, both under domestic law and under international law, was required to work towards more ambitious targets. The plaintiffs argued that the Netherlands' reduction objectives were below the standard deemed necessary by climate science to hold the increase in the global average temperature 'to well below $2{ }^{\circ} \mathrm{C}$ above pre-industrial levels'. ${ }^{65}$ They requested that the government reduce GHG emissions in the Netherlands 'to a level of $40 \%$, or at least $25 \%$, below the level of 1990 before 2020'.66 This request was formulated based on current climate science, in particular on the work of the Intergovernmental Panel on Climate Change (IPCC). ${ }^{67}$ Urgenda identified the legal bases for its claims in international climate instruments such as the UN Framework Convention on Climate Change (UNFCCC) and the Kyoto Protocol, in domestic legislation (including the Dutch Constitution), and in the European Convention on Human Rights (ECHR), arguing that the Netherlands' insufficiently ambitious action on climate change constituted a violation of its human rights obligations. ${ }^{68}$

After rejecting some of the plaintiffs' arguments, ${ }^{69}$ the District Court found international climate instruments and principles, such as the precautionary principle, to be particularly relevant in defining the required standard of conduct. ${ }^{70}$ The court recognized the state's duty to ensure that the joint volume of Dutch annual GHG emissions will be reduced by at least 25 per cent at the end of 2020 compared with $1990 .^{71}$ The Court of Appeals (CA) essentially confirmed these findings, and, contrary to

63 UNEP, note 61. See also the District Court judgment in the Urgenda case, note 64.

64 Urgenda Foundation (on behalf of 886 individuals) $v$ The State of the Netherlands (Ministry of Infrastructure and the Environment), judgment of 24 June 2015, ILDC 2456 (NL 2015) (Urgenda, DC).

65 Paris Agreement, note 1, art 2.1(a).

66 Urgenda, 'Summons in the Case: Urgenda Foundation v Kingdom of the Netherlands - Final Draft Translation' (2013), 121, https://www.urgenda.nl/wp-content/uploads/Translation-Summons-in-case-Urgenda-v-Dutch-Statev.25.06.10.pdf (accessed 27 October 2020).

67 Urgenda, DC, para 4.23.

68 Urgenda, 'Summons in the Case', note 66.

69 Urgenda, DC, note 64, paras 4.42, 4.45-4.46.

70 Ibid, paras 4.53, 4.56 .

71 Ibid, para 5.1. 
the District Court, found that Urgenda could also directly invoke Articles 2 and 8 of the ECHR. ${ }^{72}$ It derived the state's duty of care from the positive obligation under the ECHR to take concrete actions to prevent a future violation of the relevant interests. ${ }^{73}$ Thus, the Court of Appeals concluded that the state had done 'too little to prevent a dangerous climate change' and was doing too little to catch up. ${ }^{74}$ On 20 December 2019, the Supreme Court at The Hague confirmed what can undoubtedly be termed as a landmark decision in the realm of climate change and human rights. ${ }^{75}$

The Supreme Court judgment confirms that climate law and environmental law principles are to be read as integral elements of the due diligence obligations that states have under international human rights law. As discussed in section III below, a similar integrated approach is necessary to interpret the standard of conduct expected of businesses under the UNGPs. Importantly, the District Court found no merit to the Netherlands' defence that the state could not be seen as 'one of the causers of an imminent climate change' because it did not itself emit GHG. ${ }^{76}$ In fact, the state has 'the power to control the collective Dutch emission level' and is therefore required 'to take on a high level of care' to facilitate a transition to a sustainable society. ${ }^{77}$ This obligation, which stands regardless of the relatively small contribution of a state to the global emissions volume, ${ }^{78}$ also entails increasing the availability of nonfossil energy sources. ${ }^{79}$ Here lies the key to the political 'intractability' of the climate change problem, as the measures required to make even the $2^{\circ} \mathrm{C}$ target (not to mention the $1.5^{\circ} \mathrm{C}$ aspiration $^{80}$ ) realistic require phasing out fossil fuels as the basis of the modern industry. ${ }^{81}$ In spite of the high political sensitivity of the matter, the Urgenda lawsuit

72 The CA found that while Article 34 bars 'public interest action' before the European Court of Human Rights, it does not prevent Urgenda from raising Article 2 and Article 8 in the Dutch judicial system, which allows for public interest litigation. The State of the Netherlands v Urgenda Foundation, Judgment of 9 October 2018, C/09/456689/ HA ZA 131396, para 35 (Urgenda, CA), https://elaw.org/system/files/attachments/publicresource/Urgenda_2018_Appeal_ Decision_Eng.pdf (accessed 17 December 2019)).

73 Ibid, para 41.

74 Ibid, para 71.

75 Mike Corder, 'Climate Activists Get Final Victory in Dutch Court Ruling', The Washington Post (20 December 2019), https://www.washingtonpost.com/business/climate-activists-final-victory-in-dutch-court-ruling/2019/12/20/ f0e51a18-2310-11ea-b034-de7dc2b5199b_story.html (accessed 20 December 2019).

76 Urgenda, DC, note 64, para 4.66.

77 Ibid.

78 Ibid, para 4.79.

79 Ibid, para 4.66.

80 Paris Agreement, note 1, art 2.1(a).

81 Thiagarajan Jayaraman, 'The Paris Agreement on Climate Change: Background, Analysis and Implications' (May 2015), https://www.researchgate.net/publication/289470031_The_Paris_Agreement_on_Climate_Change_Background_ Analysis_and_Implicattions (accessed 17 December 2019). Technological advancements giving rise to "negative emissions', for instance through the storage of $\mathrm{CO}_{2}$ underground, are at an embryonic stage and cannot bring concrete changes in the foreseeable future. Urgenda, DC, note 64, para 4.72; Henry D Jacoby and Jennifer Morris, 'Why the Next Two Years are Critical for the Paris Climate Deal's Survival', The Conversation (4 December 2018), https:// theconversation.com/why-the-next-two-years-are-critical-for-the-paris-climate-deals-survival-107931 (accessed 17 December 2019). On climate change as a 'superwicked' problem, see Richard J Lazarus, 'Superwicked Problems and Climate Change: Restraining the Present to Liberate the Future' (2009) 94:8 Cornell Law Review 1153; Kelly Levin et al, 'Overcoming the Tragedy of Superwicked Problems: Constraining Our Future Selves to Ameliorate Global Climate Change' (2012) 45 Policy Sciences 123. 
led the Netherlands to accelerate the closure of a Vattenfall coal-fired power plant, ${ }^{82}$ to impose more stringent emission caps on the remaining four coal-fired power stations (due to close by 2030), ${ }^{83}$ and to adopt a package of measures promoting a shift to cleaner energy. ${ }^{84}$

Urgenda has not remained an isolated case in Europe. In Ireland, the Supreme Court decided in 2020 that the National Mitigation Plan adopted by the government fell short of the specificity required by the Climate Action and Low Carbon Development Act, although it did not confirm the existence of a constitutional right to a healthy environment. ${ }^{85}$ A number of cases with an explicit human rights dimension are pending in Belgium ${ }^{86}$ and France. ${ }^{87}$ In Germany, two lawsuits invoke the fundamental rights protected by the German Constitution to allege the German government's insufficient action on GHG emissions and climate change. ${ }^{88}$ A lawsuit promoted against the UK government by the NGO Plan B did not succeed in compelling the authorities to raise the emission reduction targets, but it did spur a recommendation by the Climate Change Committee to review the 2050 target in light of the Paris Agreement. ${ }^{89}$ At the EU level, the 2018 'People's Climate Case' alleged the inadequacy of the EU climate targets referencing several EU and international instruments, including the EU Charter of Fundamental Rights, the UNFCCC and the Paris Agreement. ${ }^{90}$ The European General Court dismissed the claim based on the plaintiffs' lack of standing. ${ }^{91}$ In March 2019,

82 Lefteris Karagiannopoulos, 'Dutch Government Tells Vattenfall to Shut 650 MW Coal Plant by End-2019', Reuters (8 March 2019), https://www.reuters.com/article/us-netherlands-coal-vattenfall/dutch-government-tells-vattenfall-toshut-650-mw-coal-plant-by-end-2019-idUSKCN1QP1ZI (accessed 20 May 2020).

83 Robin Pascoe, 'Ministers Finalise Measures to Cut Air Pollution Following Urgenda Court Case', DutchNews.nl (25 April 2020), https://www.dutchnews.nl/news/2020/04/ministers-finalise-measures-to-cut-air-pollution-following urgenda-court-case/ (accessed 20 May 2020).

84 Urgenda, '54 Actions for 17 MTons of $\mathrm{CO}_{2}$ Reduction' (2020), https://www.urgenda.nl/en/themas/climate-case/ dutch-implementation-plan/ (accessed 20 May 2020).

85 Friends of the Irish Environment v Ireland, Judgment, Appeal No: 205/19, Judgment of 31 July 2020, https:// www.courts.ie/acc/alfresco/681b8633-3f57-41b5-9362-8cbc8e7dd9215/2020_IESC_49.pdf/pdf\#view=fitH (accessed 20 May 2020).

86 Sabin Center for Climate Change Law, 'VZW Klimaatzaak $v$ Kingdom of Belgium \& Others', http:// climatecasechart.com/non-us-case/vzw-klimaatzaak-v-kingdom-of-belgium-et-al/ (accessed 17 May 2020).

87 Sabin Center for Climate Change Law, 'Climate Litigation: Commune de Grande-Synthe v France' (2019), http:// blogs2.law.columbia.edu/climate-change-litigation/wp-content/uploads/sites/16/non-us-case-documents/2019/

20190123_Not-Yet-Available_press-release-1.pdf (accessed 17 May 2020); Notre Affaire à Tous, 'Inaction Over Climate Change; Let's Fight for Justice - Press Release' (2019), https://notreaffaireatous.org/wp-content/uploads/ 2018/12/CP-ANGLAIS.pdf (accessed 17 May 2020).

88 Sabin Center for Climate Change Law, 'Family Farmers and Greenpeace Germany v Germany' (2018), http:// climatecasechart.com/non-us-case/family-farmers-and-greenpeace-germany-v-german-government/ (the case was dismissed by the court in October 2019); 'Friends of the Earth Germany, Association of Solar Supporters, and Others v Germany' (2018), http://climatecasechart.com/non-us-case/friends-of-the-earth-germany-association-ofsolar-supporters-and-others-v-germany/ (accessed 17 December 2019).

89 Plan B, 'Plan B v UK' (30 January 2019), https://planb.earth/plan-b-v-uk/ (accessed 17 December 2019); Sara Stefanini, "'End of the Road" for UK Citizens' Climate Case Rejected by Appeal Court', Climate Home News (30 January 2019), https://www.climatechangenews.com/2019/01/30/end-road-uk-citizens-climate-case-rejected-appealcourt/ (accessed 20 May 2020).

90 Armando Ferrão Carvalho and Others v The European Parliament and the Council - 'The People's Climate Case' (2018) Case No. T-330/18, para 49, https://peoplesclimatecase.caneurope.org/wp-content/uploads/2019/05/europeangeneral-courts-order-_15.05.2019.pdf (accessed 22 April 2020).

91 Ibid. The plaintiffs will appeal. Karen Savage, 'European Court Rules Individuals Cannot Sue Over Climate Change', Climate Liability News (22 May 2019), https://www.climateliabilitynews.org/2019/05/22/european-unionclimate-change-peoples-climate-case/ (accessed 10 December 2019). 
another lawsuit was filed at the EU Court of Justice by the US and EU plaintiffs who challenge the EU's characterization of wood burning as a renewable energy source through the 2018 EU Renewable Energy Directive. ${ }^{92}$ The plaintiffs allege that the Directive will prompt the burning of forests with devastating effects for the environment, violating the plaintiffs' rights under the EU Charter of Fundamental Rights. ${ }^{93}$ If successful, the lawsuit might have an impact on corporations operating in the industry, including foreign corporations willing to export wood pellets to Europe. ${ }^{94}$

A series of lawsuits targeted the climate change responsibilities of state-owned enterprises. In Sweden, PUSH and other NGOs attempted to leverage human rights and other international standards to impact the operations of state-owned Vattenfall. The lawsuit, which mentioned the Urgenda judgment and the $R W E$ case, ${ }^{95}$ claimed that the sale by Vattenfall of coal-fired power plants and mining assets located in Germany to a foreign corporation posed an immediate risk of increase in GHG emissions. ${ }^{96}$ The plaintiffs, referencing the UN Global Compact and the OECD Guidelines, claimed that the German corporation did not meet the criteria of a responsible buyer, lacking clear environmental policies and probably aiming at expanding the mining and burning of lignite. ${ }^{97}$ PUSH argued it was irrelevant that the increased emissions would be produced in a country other than Sweden, given the global dimension of the climate change phenomenon. ${ }^{98}$ The case was dismissed by the court, which found that the plaintiffs had failed to demonstrate that they had suffered an injury from the governmental decisions. ${ }^{99}$

In 2007, the European Social Committee found Greece in violation of several provisions of the European Social Charter for failing to comply with its obligation to protect public health against air pollution by authorizing the Public Power Corporation to operate lignite coal mines and coal-fired power plants without adequate impact assessment and mitigation measures. ${ }^{100}$ The UNFCCC, the Kyoto Protocol and the Aarhus Convention were

\footnotetext{
92 Megan Darby, 'Burning Wood for Power Breaches EU Treaty, New Lawsuit Claims', Climate Home News (4 March 2019), https://www.climatechangenews.com/2019/03/04/burning-wood-power-breaches-eu-treaty-new-lawsuitclaims/ (accessed 10 December 2019).

93 EU Biomass Legal Case, 'EU Renewable Energy Policy Devastates Forests and Accelerates Climate Change, New Lawsuit Claims', press release (4 March 2019), http://eubiomasscase.org/eu-renewable-energy-policy-devastatesforests-and-accelerates-climate-change-new-lawsuit-claims/ (accessed 21 May 2020). For a critical study, see Saul Elbein, 'Europe's Renewable Energy Policy is Built on Burning American Trees', Vox (4 March 2019), https://www. vox.com/science-and-health/2019/3/4/18216045/renewable-energy-wood-pellets-biomass (accessed 10 December 2019).

94 EU Biomass Legal Case, note 93.

95 'PUSH Sweden, Nature and Youth Sweden and Others $v$ Government of Sweden - unofficial translation of Summons' (15 September 2016), paras 114 and 117-118, http://blogs2.law.columbia.edu/climate-change-litigation/ wp-content/uploads/sites/16/non-us-case-documents/2016/20160915_3649_summons.pdf (accessed 10 December 2019).

96 Ibid, para 122.

97 Ibid, paras 66-78.

98 Ibid, para 107.

99 Grantham Research Institute on Climate Change and the Environment, 'PUSH Sweden, Nature \& Youth Sweden and Others $v$ Government of Sweden', https://climate-laws.org/geographies/sweden/litigation_cases/push-swedennature-youth-sweden-et-al-v-government-of-sweden (accessed 27 October 2020).

100 European Social Committee, Marangopoulos Foundation for Human Rights (MFHR) v Greece, Complaint No. 30/ 2005 (Decision, 2006), http://blogs2.law.columbia.edu/climate-change-litigation/wp-content/uploads/sites/16/non-uscase-documents/2007/20070607_Complaint-No.-302005_decision-1.pdf (accessed 10 December 2019).
} 
referenced among the relevant legal bases. ${ }^{101}$ Another interesting example, although not including an explicit reference to human rights, lies in the formal objection filed by the government of Micronesia under the Czech Republic's environmental impact assessment law to ask for a Transboundary Environmental Impact Assessment (TEIA). ${ }^{102}$ For the first time a TEIA was requested in relation to the climate change effects of a project, namely the proposed expansion of the Prunérov II coal-fired power plant. ${ }^{103}$ The government recognized Micronesia as an affected state and requested the state-owned corporation $\mathrm{CEZ}$ to put in place a compensation plan with the aim to offset five million tons of $\mathrm{CO}_{2} \cdot{ }^{104}$

There are other examples in Europe of litigation targeting specific business projects on the basis of their impact on climate change. These include the challenges to airports expansion filed in the UK, ${ }^{105}$ Austria ${ }^{106}$ and Ireland, ${ }^{107}$ where plaintiffs considered the construction of new airport runways as contrary to the mitigation targets binding the respective governments under international climate law. The UK and Ireland lawsuits explicitly referenced international human rights law, besides climate and environmental standards. While unsuccessful, the UK lawsuit contributed to pressure the government into reconsidering the viability of the Heathrow airport expansion, which it committed to do, also in light of the Parliament's recognition of a climate and ecological emergency. ${ }^{108}$ The Irish lawsuit did not succeed either, although it led an Irish court to recognize that the Irish Constitution implicitly enshrines a right to a healthy environment that constitutes 'an essential condition for the fulfilment of all human rights' ${ }^{109}$

Important indications concerning the climate change dimension of states' responsibility under international human rights law are likely to come, in the near future, from the UN human rights treaty bodies. ${ }^{110}$ Currently, the Human Rights

\footnotetext{
101 Ibid, para 113.
}

102 Environmental Rights Database, 'Federated States of Micronesia (FSM) Request for Czech Government to Consider the Transboundary Environmental Effects of a Coal Plant', http://environmentalrightsdatabase.org/ federated-states-of-micronesia-fsm-request-for-czech-government-to-consider-the-transboundary-environmentaleffects-of-a-coal-plant/ (accessed 22 May 2020).

103 Ibid.

104 Ibid. The plant is still causing controversy for its climate change impact. Frank Bold Society, 'Lignite Power Plant Prunéřov II', http://en.frankbold.org/our-work/campaign/lignite-power-plant-prunerov-ii (accessed 10 December 2019).

$105 R$ (on the application of the London Borough of Hillingdon and others) v Secretary of State for Transport (2010) EWHC 626, https://www.judiciary.uk/wp-content/uploads/2019/05/Heathrow-main-judgment-1.5.19.pdf (accessed 10 December 2019).

106 In re Vienna-Schwechat Airport Expansion (Judgment of 29 June 2017), W109 2000179-1/291E, http:// climatecasechart.com/non-us-case/in-re-vienna-schwachat-airport-expansion/ (accessed 10 December 2019).

107 Friends of the Irish Environment CLG v Fingal County Council (2017), No. 344 JR, http://climatecasechart.com/ non-us-case/friends-irish-environment-clg-v-fingal-county-council/ (accessed 10 December 2019).

108 'Government Tells Plan B it May Review Heathrow Plans' (12 May 2019), https://planb.earth/government-tells-planb-it-may-review-heathrow-plans/ (accessed 10 December 2019); 'UK Parliament Declares Climate Change Emergency', BBC News (1 May 2019), https://www.bbc.com/news/uk-politics-48126677 (accessed 10 December 2019 ).

109 As mentioned in section II.B, however, the Supreme Court in 2020 did not confirm this finding. Friends of the Irish Environment CLG v Fingal County Council, note 107.

110 The UN committees have repeatedly affirmed that regulating the conduct of businesses to prevent human rights violations abroad is part of the due diligence obligations of states. This conclusion might in the future be spelled out more explicitly with regard to the human rights impacts of climate change. CERD, 'Concluding Observations: Canada', CERD/C/CAN/CO/18 (2007), para 17; CESCR, 'General Comment No. 24 on State Obligations Under the International Covenant on Economic, Social and Cultural Rights in the Context of Business Activities', E/C.12/GC/24 (2017), paras 30-35; CRC, 'General Comment 16: State Obligations Regarding the Impact of the Business Sector on Children's Rights', CRC/C/GC/16 (2013), para 45. 
Committee is dealing with the first individual petition explicitly addressing the state's duty to address climate change and its adverse human rights impacts, ${ }^{11}$ and the Committee on the Rights of the Child will soon examine a communication against several states that frames climate change as a 'children's rights crisis'. ${ }^{112}$ The European Court of Human Rights has often sanctioned states for failing to act upon available scientific knowledge to prevent or stop harm deriving from industrial pollution and accidents. ${ }^{113}$ While a climate change action popularis could not be heard by the Court, the due diligence standards its jurisprudence has elaborated could apply to cases of climate-impacting industrial plants, provided an interference with the applicants' private sphere can be demonstrated. ${ }^{114}$ Currently, the Youth for Climate Justice case is pending before it, filed by six Portuguese youth against 33 countries accused of failing to take sufficient action on climate change. ${ }^{115}$

Although existing case law on the climate-related responsibilities of public authorities is at a relatively early stage and still underdeveloped, it allows us to draw some initial conclusions regarding the emerging concept of climate due diligence. In particular, this case law seems to confirm the central importance of the two main themes identified in section II.A, namely, risk mitigation and integration. Public authorities, which, in the words of the Urgenda court, have the power to control the collective emission level, are increasingly called upon to integrate adequate climate targets into their own policies, and, at the same time, not to allow corporate activities and projects to frustrate the objectives of the Paris Agreement. The transition towards a more sustainable society could then imply stricter regulation of corporate emissions and of projects that would raise their level. Some of the cases referenced also insist on adequate impact assessments taking climate into account. Thus, existing examples of litigation, both against corporations and public authorities, confirm the importance for corporations to integrate the climate change dimension into their processes and policies, as well as to work towards a mitigation of their climate impacts. While it is not possible to predict how the case law will evolve, with many relevant cases still pending and new ones being filed, ${ }^{116}$ it is becoming clear how

\footnotetext{
111 'Petition of Torres Strait Islanders to the United Nations Human Rights Committee Alleging Violations Stemming from Australia's Inaction on Climate Change' (2019), http://climatecasechart.com/non-us-case/petition-of-torres-straitislanders-to-the-united-nations-human-rights-committee-alleging-violations-stemming-from-australias-inaction-onclimate-change/ (accessed 27 October 2020). In a previous petition, the Committee affirmed the state's duty to consider climate change-induced threats to the right to life for the purpose of non-refoulement (Human Rights Committee, Ioane Teitiota $v$ New Zealand, CCPR/C/127/D/2728/2016 (7 January 2020), https://www.refworld.org/cases,HRC,5e26f7134. html (accessed 26 October 2020)).

112 Sacchi et al $v$ Argentina et al, Communication to the Committee on the Rights of the Child (23 September 2019), para 13, http://blogs2.law.columbia.edu/climate-change-litigation/wp-content/uploads/sites/16/non-us-case-documents/ 2019/20190923_Not-available_petition-1.pdf (accessed 27 October 2020).

113 ECtHR, Cordella et al v Italy, Apps nos 54414/13 and 54624/15 (Judgment of 24 January 2019); ECtHR, López Ostra v Spain, App no 16798/90 (Judgment of 9 December 1994); ECtHR, Öneryildiz v Turkey, App no 48939/99 (Judgment of 30 November 2004).

114 Fadeyeva v Russia, App no 55723/00 (Judgment of 9 June 2005), para 70.

115 Sabin Center for Climate Change Law, 'Youth for Climate Justice v Austria et al' (2020), http:// climatecasechart.com/non-us-case/youth-for-climate-justice-v-austria-et-al/ (accessed 10 September 2020).

116 Ibid; Sabin Center for Climate Change Law, 'Neubauer et al v Germany' (2020), http://climatecasechart.com/nonus-case/neubauer-et-al-v-germany/ (accessed 10 September 2020); Sabin Center for Climate Change Law, 'Greenpeace et al v Austria' (2020), http://climatecasechart.com/non-us-case/greenpeace-v-austria/ (accessed 10 September 2020).
} 
corporations failing to take action in the two key areas of integration and risk mitigation are increasingly at risk of incurring complex litigation and reputational loss. ${ }^{117}$ In addition, given the changing regulatory and financial landscape, further pressure is likely to come from a corporation's own shareholders. ${ }^{118}$

Some questions remain as to the features and scope of climate due diligence as a component of HRDD, given that a fully-fledged definition cannot be extrapolated from existing jurisprudence, yet. Such a definition can be better articulated by reference to the normative categories of the UNGPs. It should look beyond the responsibilities of big emitters, which are often the target of strategic litigation, and conceptualize the climaterelated responsibility of corporations of all sizes and sectors. This question is addressed below in section III.

\section{A Holistic Approach to Human Rights Due Diligence}

Climate change is a direct and serious threat to the enjoyment of human rights, ${ }^{119}$ and as such, a relevant dimension of both the state duty to protect and of the corporate responsibility to respect human rights. ${ }^{120}$ The Office of the High Commissioner for Human Rights (OHCHR) was clear in affirming that businesses 'must be accountable for their climate impacts and participate responsibly in climate change mitigation and adaptation efforts with full respect for human rights'. ${ }^{121}$ Climate change-related human rights impacts are, therefore, a necessary dimension of the HRDD processes that businesses are required to put in place in order to fulfil their responsibility to respect. ${ }^{122}$

HRDD is an open-ended standard, and as such it carries an inherent degree of flexibility. Precisely because climate, environmental and human rights challenges are

\footnotetext{
117 Task Force on Climate-Related Financial Disclosures, 'Recommendations of the Task Force on Climate Related Financial Disclosures' (2017), 5, https://www.fsb-tcfd.org/publications/final-recommendations-report/ (accessed 10 September 2020).

118 The NGO ClientEarth successfully leveraged the fiduciary duty owed by the board of the Polish utility Enea to the corporation's shareholders. The court declared null and void the shareholder resolution allowing the construction of a coal-fired power plant that, according to 'compelling evidence' from independent experts, would harm the interests of the corporation and its shareholders given the increasing concerns of global institutional investors about the financial implications of investment in coal assets. ClientEarth, 'Ostrołęka C: Energa's and Enea's Board Members' Fiduciary Duties to the Companies and Shareholders' (2018), https://www.documents.clientearth.org/wp-content/uploads/library/ 2018-09-20-clientearth-briefing-ostroleka-c-energa-and-enea-board-members-fiduciary-duties-to-the-companies-andshareholders-ce-en.pdf (accessed 19 December 2019). A similar strategy is being pursued also in a number of extra-EU cases. Maysa Zorob and Antonella Angelini, 'Are Shareholders the New Champions of Climate Justice?', BHRRC (2019), https://www.business-humanrights.org/zh-hans/node/190191 (accessed 22 May 2020). See also Sabin Center for Climate Change Law, 'McVeigh v. Retail Employees Superannuation Trust' (2018), http://climatecasechart.com/nonus-case/mcveigh-v-retail-employees-superannuation-trust/ (accessed 10 September 2020).

119 ClientEarth, 'Understanding Human Rights and Climate Change', Submission to COP21 (2015), https:// www.business-humanrights.org/sites/default/files/CHR-NI-2016-0001\%20-\%20Amicus\%20Curiae\%20Brief\% 20Presented\%20by\%20ClientEarth\%20-\%20Annex\%20A.pdf (accessed 18 May 2020).

120 OHCHR, 'Climate Change and the UNGPs', https://www.ohchr.org/EN/Issues/Business/Pages/Climate-Changeand-the-UNGPs.aspx (accessed 18 May 2020).

121 OHCHR, 'Key Messages on Human Rights and Climate Change', para 8, https://www.ohchr.org/Documents/ Issues/ClimateChange/KeyMessages_on_HR_CC.pdf (accessed 18 May 2020).

122 European Commission (EC), 'Study on Due Diligence Requirements Through the Supply Chain' (2020) 185, https://op.europa.eu/en/publication-detail/-/publication/8ba0a8fd-4c83-11ea-b8b7-01aa75ed71a1/language-en (accessed 21 May 2020).
} 
fundamentally interrelated, a holistic approach ${ }^{123}$ to HRDD is needed, one in which the standard of conduct is interpreted in the light of environmental law, climate law, as well as international human rights law. This approach, as illustrated in section II.B, has been successfully adopted in the Urgenda case against the state of the Netherlands, and should arguably be applied, mutatis mutandis, to corporate HRDD. As Olawuyi notes, Article 31 of the Vienna Convention on the Law of the Treaties requires states to consider all relevant rules of international law applicable between the parties when interpreting specific treaty obligations, a principle that 'underpins the significance of reading international law instruments in mutually supportive ways'. ${ }^{124}$ Similarly, the fact that the UNGPs do not expressly refer to environmental rights or international environmental law as part of the minimum business responsibility does not bar a holistic interpretation of the due diligence standard. ${ }^{125}$ Indeed, environmental law and human rights law principles are not only compatible, but, in many respects, mutually reinforcing. Both under environmental law and human rights law, due diligence requires ensuring information and participation rights, fundamental conditions of the legitimacy of state action and of the corporate 'social licence' to operate. ${ }^{126}$ Key tenets of environmental law such as the precautionary approach and the prevention principle largely align with the UNGPs, as they require preventing irremediable harms and prioritizing interventions based on the severity of risks. ${ }^{127}$ The Oslo Principles on Global Obligations to Reduce Climate Change state that there is 'clear and convincing evidence' that anthropogenic GHG emissions are altering the climate in a way that poses 'grave risks of irreversible harm to humanity'. ${ }^{128}$ Accordingly, the precautionary approach requires GHG emissions to be reduced at a pace and level 'based on any credible and realistic worst-case scenario accepted by a substantial number of eminent climate change experts'. ${ }^{129}$ The Principles also remark that no country or enterprise is relieved of its responsibility, however small its contributions to total GHG emissions. ${ }^{130}$ In the same way, the UNGPs' HRDD standard applies to all business enterprises, regardless of their size, sector, location, ownership and structure. $^{131}$

Keeping climate due diligence and HRDD in separate silos could lead to ineffective or inconsistent actions, yet, as noted by Olawuyi in relation to carbon investments,

\footnotetext{
123 Damilola S Olawuyi, The Human Rights-Based Approach to Carbon Finance (Cambridge: Cambridge University Press, 2016) 153-155.

124 Ibid, 156-157.

125 The UNGPs only mention the International Bill of Human Rights and the principles concerning fundamental rights set out in the International Labour Organization's Declaration on Fundamental Principles and Rights at Work, although they do recognize that 'depending on circumstances, business enterprises may need to consider additional standards'. OHCHR, 'UN Guiding Principles on Business and Human rights', A/HRC/17/31 (2011) (UNGPs), Commentary to Principle 12.

126 Damilola S Olawuyi, 'Climate Justice and Corporate Responsibility: Taking Human Rights Seriously in Climate Actions and Projects' (2016) 34:1 Journal of Energy \& Natural Resources Law 1, 18.

127 EC, note $122,182$.

128 'Oslo Principles on Global Obligations to Reduce Climate Change', Global Justice Program (2015), 3 (emphasis added), https://globaljustice.yale.edu/sites/default/files/files/OsloPrinciples.pdf (accessed 27 October 2020).

129 Ibid.

130 Ibid, 5.

131 UNGPs, note 125, General Principles.
} 
corporations that adopt internal carbon footprint and GHG policies often fail to pay equal attention to human rights risk management policies. ${ }^{132}$ A 2019 report by the Alliance for Corporate Transparency analysing disclosure of 1,000 corporations pursuant to the EU Non-Financial Reporting Directive found that 'the vast majority of corporations fail to have specific risk mitigation strategies'. ${ }^{133}$ Less than 32 per cent report on such a strategy, while only 23 per cent address specific climate risks. ${ }^{134}$ Moreover, the progress made since 2011 should not overshadow the fact that HRDD is not fully implemented or comprehended by businesses yet. A 2019 CHRB assessment of the human rights performance of 200 of the world's largest publicly traded corporations identified HRDD as a key weak performance area, with nearly half of the surveyed corporations scoring no points across the relevant indicators. ${ }^{135}$ In part, these shortcomings are compounded in Europe by the increasingly fragmented regulatory landscape, which might be a source of legal uncertainty, ${ }^{136}$ and is leading some businesses to support the option of a EU-wide HRDD framework introducing uniform standards. ${ }^{137}$ The contribution of this section is twofold. First, building on the UNGPs' normative framework, it argues that climate due diligence as a standard of conduct binds all businesses as an inherent dimension of the HRDD standard. Second, based on the UNGPs' articulation of HRDD as a corporation process ${ }^{138}$ and in light of emerging climate change litigation, it explores the main components of a fully-fledged process of climate due diligence.

\section{A. Climate Due Diligence as an Inherent Dimension of Human Rights Due Diligence}

To pinpoint specific responsibilities in the case of climate change is particularly complex, in that the phenomenon as such is brought about by the cumulative effects of acts (and omissions) carried out by a large number of public and private subjects over the span of decades. A case for 'cumulative contribution' can be made, as 'multiple firms each

\footnotetext{
132 Olawuyi, note $123,407$.

133 Alliance for Corporate Transparency, '2019 Research Report: An Analysis of the Sustainability Reports of 1000 Companies Pursuant to the EU Non-Financial Reporting Directive' (2019), Foreword, https://www.allianceforcorp oratetransparency.org/assets/2019_Research_Report\%20_Alliance_for_Corporate_Transparency-7d9802a0c18c9f13017 d686481bd2d6c6886fea6d9e9c7a5c3cfafea8a48b1c7.pdf (accessed 27 October 2020).

134 Ibid.

135 CHRB, '2019 Key Findings - Agricultural Products, Apparel, Extractives \& ICT Manufacturing' (2019) 6, https:// www.corporatebenchmark.org/sites/default/files/2019-11/CHRB2019KeyFindingsReport.pdf (accessed 27 October 2020).

136 EC, note 122, 94-95.

137 ECCJ, 'Evidence for Mandatory HRDD Legislation' (2018), http://corporatejustice.org/policy-evidence-mhrddnovember-2018-final.pdf (accessed 17 December 2019); Benjamin Fox, 'Companies Will Support EU Law on Due Diligence, But Need Assurances on Liability', Euractiv (19 March 2019), https://www.euractiv.com/section/economyjobs/interview/companies-will-support-eu-law-on-due-diligence-but-need-assurances-on-liability/ (accessed 27 October 2020).

138 The distinction between HRDD as a standard of conduct on the one hand, and as a business process on the other, builds on the work of Bonnitcha and McCorquodale. Jonathan Bonnitcha and Robert McCorquodale, 'The Concept of "Due Diligence" in the UN Guiding Principles on Business and Human Rights' (2017) 28 European Journal of International Law 899.
} 
contribute a relatively minor amount to the creation of a substantial impact'. ${ }^{139}$ The UNGPs' notion of contribution entails an element of causality, ${ }^{140}$ which, in the case of climate change, is typically a double causality, as pointed out by Birchall: 'is climate change causing human rights impacts, and are businesses contributing to climate change?'. ${ }^{141}$ These questions are particularly tricky when the goal is to attribute liability, as the plaintiffs might need to show both that climate change is the cause of a specific impact (e.g., the melting of a glacier endangering a community) and that the defendant has contributed to climate change in a certain measure. While fraught with obstacles, this path is being explored by lawyers, as shown by the Lluya $v$ RWE lawsuit mentioned earlier and by some non-EU cases. ${ }^{142}$

However, in the UNGPs, 'contribution' broadly indicates 'an action or omission that assists or helps bring about the underlying violation, or increases the likelihood of the event', ${ }^{143}$ and does not correspond to a 'but for' standard. In addressing the applicability of the UNGPs to the banking sector, the OHCHR makes it clear that even minority shareholding in a project that harms human rights can constitute contribution, when the investor does not take adequate steps to mitigate the impact. ${ }^{144}$ The size of the investment, or, in the case of climate change, the amount of a corporation's GHG emissions, is only one of the factors that need to be considered on a case-by-case basis in assessing whether a corporation has discharged its responsibility to respect. The severity of the impact defined as the impact's scale and irremediable character - needs to be given primary consideration. ${ }^{145}$ Other essential factors include the predictability of the harm ${ }^{146}$ and 'the quality of any mitigating steps' taken by the corporation to address it. ${ }^{147}$ A corporation contributing in a small percentage to global GHG emissions might be seen as just 'linked to' the adverse impacts caused by climate change, and not necessarily 'contributing' to them. However, in light of the severity of climate change and of the widely available knowledge about its likely and actual consequences, ${ }^{148}$ many of which are large scale and

\footnotetext{
139 David Birchall, 'Irremediable Impacts and Unaccountable Contributors: The Possibility of a Trust Fund for Victims to Remedy Large-Scale Human Rights Impacts' (2019) 3:25 Australian Journal of Human Rights 428, 429.

140 OHCHR, 'Response to Request from BankTrack for Advice Regarding the Application of the UNGP in the Context of the Banking Sector' (2017) 5, https://www.ohchr.org/Documents/Issues/Business/InterpretationGuidingPrinciples.pdf (accessed 18 May 2020).

141 Ibid, 6.

142 See, for instance: Rhode Island v Chevron Corp, 2019 WL 3282007 (DRI 22 July 2019); Smith v Fonterra CoOperative Group Ltd and Ors (2020) NZHC 419 (High Court of New Zealand).

143 Debevoise Business Integrity Group and Enodo Rights, 'Practical Definitions of Cause, Contribute, and Directly Linked to Inform Business Respect for Human Rights - Discussion Draft' (2017), 24-25, https://www.businesshumanrights.org/sites/default/files/documents/Debevoise-Enodo-Practical-Meaning-of-Involvement-Draft-2017-0209.pdf (accessed 18 May 2020).

144 OHCHR, note $140,5$.

145 UNGPs, note 125, GPs 14, 19, 24.

146 More specifically, the extent to which the corporation 'could or should have known about such harm'. John Ruggie, 'Comments on Thun Group of Banks Discussion Paper on the Implications of UN Guiding Principles 13 and 17 in a Corporate and Investment Banking Context' (2017) 2, https://www.ihrb.org/uploads/submissions/John_Ruggie_ Comments_Thun_Banks_Feb_2017.pdf (accessed 27 October 2020)).

147 Ibid.

148 As Savaresi and Hartman point out, "climate change is predicted to cause unprecedented damage to property, persons and the environment. This damage is predictable, but only to the extent that we know it will happen, not where and when'. Savaresi and Hartman, note 35, 6 .
} 
irremediable, a corporation that fails over time 'to take reasonable steps to seek to prevent or mitigate the impact [...] could eventually be seen to be facilitating the continuance of the situation', thus eventually finding itself in a position of 'contribution' ${ }^{149}$ As recognized by the $\mathrm{OHCHR}^{150}$ and Ruggie, ${ }^{151}$ direct 'linkage' and 'contribution' to human rights impacts are placed on a continuum, and a corporation can shift from the former to the latter if it fails to exercise HRDD. Thus, regardless of any current and future developments on the litigation front, the UNGPs do not allow corporations to disregard their climate due diligence based on the relatively small size of their emissions. A teleological reading of the UNGPs reinforces this finding, as it would be incoherent, within a framework premised on the need to close the persisting gaps in the interlinked responsibilities of states and corporations, to allow for a 'responsibility void' ${ }^{152}$ in relation to large-scale human rights impacts brought about by the cumulative negligence of multiple actors. ${ }^{153}$

\section{Climate Due Diligence as a Business Process}

According to the UNGPs, all business enterprises must have in place a process of HRDD whose complexity will vary depending on an enterprise's specific features and risk profiles. ${ }^{154}$ This section shows that the process of climate due diligence, as a component of HRDD, should have a similar structure and be integrated as much as possible into the former. ${ }^{155}$ The specific steps required by each corporation and investor will be heavily influenced by the size, sector, nature and context of its operations. ${ }^{156}$ What has been referred to in section II as risk mitigation, for instance, might mean very different things for different corporations, depending on their risk profiles. Studies are starting to quantify the individual contributions of corporations to GHG emissions, showing that, in some cases, such individual shares are far from negligible. ${ }^{157}$ The energy sector, for instance, is by far the main producer of GHG emissions, being responsible for 73 per cent of emissions worldwide. ${ }^{158}$ Corporations

\footnotetext{
149 OHCHR, note 140, 7. Contribution, in turn, implies a responsibility of remediation. UNGPs, note 125, Principle 22.

150 OHCHR, note 140, 6-7.

151 Ruggie, note 146, 2.

152 'A responsibility void is a situation in which a combination of actions by different individuals leads to an outcome for which none of the individuals involved can be said to be responsible'. Matthew Braham and Martin van Hees, 'Voids or Fragmentation: Moral Responsibility For Collective Outcomes' (2018) 128:612 The Economic Journal 2.

153 Birchall observes that 'such impacts can be captured by the UNGPs demonstrates the UNGPs' transformative potential to reshape global business'. Birchall, note 139, 429.

154 UNGPs, note 125, Principle 17.

155 This is in line with the recommendations of the IBA Task Force: IBA Climate Change Justice and Human Rights Task Force, 'Achieving Justice and Human Rights in an Era of Climate Disruption' (2014) 16-17, https:// www.ibanet.org/PresidentialTaskForceClimateChangeJustice2014Report.aspx (accessed 9 September 2020).

156 UNGPs, note 125, Principle 17.

157 According to a 2019 study, 20 companies caused 35 per cent of all energy-related carbon dioxide and methane worldwide since 1965. Matthew Taylor and Jonathan Watts, 'Revealed: The 20 Firms Behind a Third of All Carbon Emissions', The Guardian (9 October 2019), https://www.theguardian.com/environment/2019/oct/09/revealed-20firms-third-carbon-emissions (accessed 18 May 2020). See also Brenda Ekwurzel et al, 'The Rise in Global Atmospheric $\mathrm{CO}_{2}$, Surface Temperature, and Sea Level from Emissions Traced to Major Carbon Producers' (2017) 144 Climatic Change 579.

158 Mengpin Ge, '4 Charts Explain Greenhouse Gas Emissions by Countries and Sectors', World Resources Institute (2020), https://www.wri.org/blog/2020/02/greenhouse-gas-emissions-by-country-sector (accessed 21 May 2020).
} 
belonging to high-risk sectors arguably have an enhanced due diligence responsibility ${ }^{159}$ to stop contributing to the human rights impacts - and, ultimately, to the existential threat caused by anthropogenic climate change. In the case of some energy corporations, this responsibility might directly call into question their core business, especially as lowcarbon options become more available. ${ }^{160}$ Importantly, in the same way as, under the UNGPs, a corporation's failure to address its human rights impacts cannot be offset by the corporation's voluntary corporate social responsibility initiatives, ${ }^{161}$ it is doubtful that purchasing a carbon offset would extinguish the corporation's responsibility to stop its contribution to global warming. ${ }^{162}$

Besides big emitters, all businesses, regardless of their size and sector, should have in place policies and processes capable of capturing and addressing their actual and potential climate-related impacts. Risk assessment ${ }^{163}$ constitutes, indeed, a necessary step to identify not only the level of a corporation's GHG emissions, but also the climate change-related vulnerabilities of workers, ${ }^{164}$ individuals and communities, for instance when deploying projects that could put a burden on local natural resources. ${ }^{165}$ Failing to consider environmental and human rights impacts as interlinked might lead to ineffective or counterproductive actions and, ultimately, higher costs. ${ }^{166}$ For this reason, while this step could be carried out through consolidated processes of impact assessment, Human Rights Impact Assessments (HRIAs) and Environmental and Social Impact Assessments (ESIAs) should be duly integrated and account for both actual and potential risks. ${ }^{167}$ Importantly, the impacts to be considered are all those that the corporation might cause or contribute to, but also those directly linked to the corporation by its business relationship, as in the case of an investor holding shares in projects that produce high levels of emissions. ${ }^{168}$ As shown by the

\footnotetext{
159 The concept of enhanced HRDD is normally linked to conflict-affected contexts. UN Working Group on Business and Human Rights, 'Statement on the Implications of the Guiding Principles on Business and Human Rights in the Context of Israeli Settlements in the Occupied Palestinian Territory' (2014), 14, https://www.ohchr.org/Documents/ Issues/Business/OPTStatement6June2014.pdf (accessed 27 October 2020). However, it can be argued that it is applicable to high risk of contribution to large-scale and irremediable human rights impacts. See, for instance, Jessica Evans, 'Human Rights: Why and How the World Bank Should Pursue Abuse-Free Development and Protect Against Rights Violations Linked to its Projects' in Michael M Cernea and Julie K Maldonado, Challenging the Prevailing Paradigm of Displacement and Resettlement: Risks, Impoverishment, Legacies, Solutions (London: Routledge, 2018) $293,311$.

160 The pace of the shift towards low-carbon energy patterns, however, also depends on technological progress and public policy incentives whose developments are still difficult to predict. Tony Addison, 'Climate Change and the Extractives Sector', in Tony Addison and Alan Roe (eds), Extractive Industries: The Management of Resources as a Driver of Sustainable Development (Oxford: Oxford University Press, 2018) 460, 461.

161 UNGPs, note 125, Principle 11.

162 On this point, see Sara L Seck, 'Climate Change, Corporate Social Responsibility, and the Extractive Industries' (2017) 11, https://papers.ssrn.com/sol3/papers.cfm?abstract_id=3244047 (accessed 11 September 2020).

163 UNGPs, note 125, Principles 17 and 18.

164 ILO, 'Climate Change, Displacement and Labour Migration', https://www.ilo.org/global/topics/labour-migration/ climate-change/green-jobs/lang-en/index.htm (accessed 21 May 2020).

165 Motoko Aizawa, 'Staying Human-Centric at the Intersection of Climate Change and Human Rights' (2016) 34:1 Journal of Energy \& Natural Resources Law 86, 90; Merrick Hoben and Larry Dixon, 'Extractives and Climate Change: The Unspoken Community Impact' (26 February 2020), https://www.cbi.org/article/extractives-and-climate-changethe-unspoken-community-impact/ (accessed 21 May 2020).

166 Aizawa, note $165,90$.

167 Ibid.

168 UNGPs, note 125, Principle 17.
} 
complaint filed with the Dutch NCP against ING, it is a responsibility of the relevant corporation to find ways to measure its own impacts, ${ }^{169}$ a task that is being facilitated by advancements in climate science and improved availability of climate data. ${ }^{170}$ The corporation then needs to take steps to address the identified risks, performing actions of risk mitigation that are not necessarily concerned (only) with the mitigation of a corporation's own emissions. When other due diligence steps prove to be impracticable or ineffective, a corporation might be required to take more radical steps, such as divesting from a project or severing a business relationship. ${ }^{171}$ An interesting example, in this respect, is the 2020 decision of the Norwegian Government Pension Fund Global to divest from four corporations, for the first time, based on an 'unacceptable level of greenhouse gas emissions'. ${ }^{172}$ Crucial in the decision was the fact that the corporations had no specific plans to reduce emissions to at least the global average 'within a reasonable period of time'. ${ }^{173}$ The fact that the Canadian businesses concerned are subjected to a regulatory regime less stringent than the EU Emissions Trading System was not considered as a defence for their failure to exercise climate due diligence. ${ }^{174}$

As climate litigation shows, corporations might be required to set concrete climate targets, especially when the risk assessment highlights the need for risk mitigation carried out through significant reduction of emissions. Climate targets should be integrated into the policy commitment that the UNGPs require to adopt at the senior management level, alongside human rights targets. ${ }^{175}$ The UNGPs also require monitoring the results of steps taken ${ }^{176}$ as well as communicating them to the public. ${ }^{177}$ Disclosure, according to the International Bar Association (IBA) Task Force, should cover the risks associated to 'all major subsidiaries and affiliates' and, if practicable, to the corporation's supply chain. ${ }^{178}$ The examples of litigation above show how corporations who fail on climate change transparency increasingly risk being the targets of criticism and lawsuits. Moreover, a growing number of stock exchanges require mandatory environmental, social and governance (ESG) reporting, including disclosure on climate-related risks. ${ }^{179}$ Finally, the UNGPs mandate that "where business enterprises identify that

\footnotetext{
169 See section II.A.2 above.

170 Aizawa, note $165,90$.

171 UNGPs, note 125, Commentary to Principle 17.

172 NBIM, 'Exclusion Decisions and Decisions to Revoke Exclusion' (2020), https://www.nbim.no/en/the-fund/newslist/2020/exclusion-decisions-and-decisions-to-revoke-exclusion/ (accessed 21 May 2020). On divestment, see Sibylle Braungardt, Jeroen van den Bergh and Tessa Dunlop, 'Fossil Fuel Divestment and Climate Change: Reviewing Contested Arguments' (2019) 50 Energy Research and Social Science 191.

173 NBIM, note 172.

174 Ibid

175 UNGPs, note 125, Principle 16.

176 Ibid, Principle 20.

177 Ibid, Principle 17.

178 IBA, note 155,17

179 Sustainable Stock Exchanges, '10 Years of Impact and Progress - Sustainable Stock Exchanges 2009-2019' (2019), https://sseinitiative.org/wp-content/uploads/2019/12/SSE-10-year-impact-report.pdf (accessed 27 October 2020). The UK might make climate risk reporting mandatory for the biggest publicly listed businesses based on the guidelines of the Task Force on Climate-Related Financial Disclosures. Gavin Hinks, 'UK Government Set to Implement Mandatory TCFD Reporting', Board Agenda (13 February 2020), https://www.edie.net/news/9/Investors-worth-8-5trncall-for-mandatory-climate-risk-reporting-for-big-businesses/ (accessed 27 October 2020).
} 
they have caused or contributed to adverse impacts, they should provide for or cooperate in their remediation'. ${ }^{180}$ This specific requirement arises when a direct contribution takes place, which, as discussed earlier, can be challenging but not impossible to establish, especially in the case of big emitters. ${ }^{181}$

\section{B. Climate Due Diligence and the Upcoming EU-wide Legislation on Human Rights and Environmental Due Diligence}

Elements of environmental due diligence are embedded in some existing EU policies addressing the link between business activities and climate change. The EU has committed to support the 'alignment of private investments with climate, resourceefficiency and other environmental objectives'.182 In Spring 2019, a political agreement was reached by the European Parliament and EU member states on new rules mandating disclosure requirements on ESG issues for a number of large corporations. ${ }^{183}$ The proposed regulation was saluted by the UN Environment Programme (UNEP) as the opportunity to clarify how ESG issues, including climate targets, are integrated in the fiduciary duties of investors. ${ }^{184}$ The initiative is part of a package that follows up the EU Action Plan on Financing Sustainable Growth. ${ }^{185}$ Other relevant instruments have been enacted in recent years by the EU, most notably the 2014 Non-Financial Reporting Directive on disclosure of non-financial and diversity information by large corporations. ${ }^{186}$

More specific obligations might be about to arise from the commitment, confirmed by the European Commissioner for Justice, to introduce mandatory corporate human rights and environmental due diligence legislation at the EU level. ${ }^{187}$ The European Parliament recommended in 2018 'an overarching, mandatory due diligence framework including a duty of care' to be based 'on the French Corporate Duty of Vigilance Law for corporations and investors, including banks'. ${ }^{188}$ The Commissioner's statement seems to indicate an ambitious approach on the part of the Commission, aiming at passing new legislation inspired by the French Duty of Vigilance Law, which is the first piece of legislation establishing certain big corporations' duty to prevent human rights harm and environmental damage in its operations and commercial relationships. ${ }^{189}$ The upcoming

\footnotetext{
180 UNGPs, note 125, Principle 22.

181 On the form that such remediation could take, see Birchall, note 139.

182 European Parliament (EP), 'Report on Sustainable Finance', A8-0164/2018 (2018), http:// www.europarl.europa.eu/doceo/document/A-8-2018-0164_EN.html (accessed 17 December 2019).

183 EC, 'Capital Markets Union: Commission Welcomes Agreement on Sustainable Investment Disclosure Rules' (press release, 7 March 2019), http://europa.eu/rapid/press-release_IP-19-1571_en.htm (accessed 17 December 2019).

184 UNEP, 'EU Policy Makers Achieve Political Agreement on Investor Disclosures and ESG' (7 March 2019), https:// www.unepfi.org/news/industries/investment/eu-policy-makers-achieve-political-agreement-on-investor-disclosuresand-esg/ (accessed 17 December 2019).

185 EC, note 183.

186 Directive 2014/95/EU (2014).

187 Didier Reynders in the webinar hosted by Responsible Business Conduct Working Group (29 April 2020), https:// vimeo.com/413525229 (accessed 21 May 2020). Benjamin Fox, 'New Human Rights Laws in 2021, Promises EU Justice Chief', Euractiv (30 April 2020), https://www.euractiv.com/section/global-europe/news/new-human-rights-laws-in2021-promises-eu-justice-chief/ (accessed 21 May 2020).

188 EP, note 182.

189 Ivano Alogna, quoted in EC, note 122, 182.
} 
legislation 'is set to identify, prevent, mitigate and account for human rights abuses and environmental damage linked to corporate operations, subsidiaries or value chains' ${ }^{190}$ Two aspects are especially notable in this commitment. First, like the French law, the new instrument might 'offer access to remedy for victims and strong enforcement mechanisms'. ${ }^{191}$ Although the EU, at the time of writing, is still examining the question of its own competence to regulate civil liability, the new instrument could address not only Pillar II of the UNGPs, but also Pillar III, the victims' access to remedy, which has sometimes been described as the 'forgotten pillar'. ${ }^{192}$ Second, it is anticipated that the Commission will frame the new rules as part of its Green New Deal, directly linking it to the objective to achieve carbon neutrality. ${ }^{193}$ This reinforces the expectation that the concept of human rights and environmental due diligence underlying the instrument will include, more or less explicitly, a climate change dimension. In its 2020 proposal for a Directive, the European Parliament defined due diligence as the process to identify and address several types of risks, among which are risks to the environment, 'including through climate change'. 194

Many crucial questions remain concerning the announced new legislation, starting from the foundational issue of its legal basis in EU law. The intention of the Commission seems to put in place a mandatory HRDD framework imposing a duty of care on corporations that goes beyond the transparency and reporting requirements established by existing sectoral legislation. This is in line with the recommendations expressed by the European Parliament on multiple occasions ${ }^{195}$ and with the EU Fundamental Rights Agency's Legal Opinion on improving access to remedy in the area of business and human rights. ${ }^{196}$ In presenting its Agenda for Action, the Finnish Presidency of the EU explicitly linked the need for EU-wide mandatory HRDD rules to the 'fragmented landscape of (existing and envisaged) regulatory measures governing responsible management of supply chains and due diligence', ${ }^{197}$ a fragmentation that is undermining legal certainty for businesses on the applicable human

\footnotetext{
190 Fox, note 187.

191 Ibid.

192 Lorna McGregor, 'Activating the Third Pillar of the UNGPs on Access to an Effective Remedy', EJIL:Talk! (2018), https://www.ejiltalk.org/activating-the-third-pillar-of-the-ungps-on-access-to-an-effective-remedy/ (accessed 21 May 2020).

193 Fox, note 187.

194 EP, 'Annex to the Motion for a Resolution: Recommendations as to the Content of the Proposals Requested', 2020/ 2129(INL) (11 September 2020), Article 3.

195 This in line with the recommendations expressed by the European Parliament on multiple occasions: EP, note 182, para 6, http://www.europarl.europa.eu/doceo/document/A-8-2018-0164_EN.html (accessed 17 December 2019); EP, 'European Parliament Resolution of 27 April 2017 on the EU Flagship Initiative on the Garment Sector', 2016/2140 (INI) (2017), http://www.europarl.europa.eu/doceo/document/TA-8-2017-0196_EN.html?redirect (accessed 17 December 2019). See also Responsible Business Conduct Working Group, 'Shadow EU Action Plan on the Implementation of the UN Guiding Principles on Business and Human Rights within the EU' (2019), https://responsiblebusinessconduct.eu/ wp/wp-content/uploads/2019/03/SHADOW-EU-Action-Plan-on-Business-and-Human-Rights.pdf (accessed 18 May 2020).

196 FRA, 'Improving Access to Remedy in the Area of Business and Human Rights at the EU Level - Legal Opinion' (2017), Opinion 21, https://fra.europa.eu/sites/default/files/fra_uploads/fra-2017-opinion-01-2017-business-humanrights_en.pdf (accessed 18 May 2020).

197 Finland's Presidency of the Council of the European Union, 'Agenda for Action on Business and Human Rights' (2 December 2019), para 13.
} 
rights and environmental due diligence requirements. ${ }^{198}$ Thus, it seems likely that the new legislation will have its legal basis in EU norms allowing the EU 'to approximate legislation with the object of ensuring the proper functioning of the internal market', namely rules regulating the functioning of the internal market (Article 114 TFEU) and freedom of establishment (Article 50 TFEU). ${ }^{199}$ Other crucial aspects remain to be clarified, including the scope of the new instrument (e.g., which corporations it will apply to), and the characteristics of the enforcement mechanism(s) envisaged. Moreover, although the French law is a promising model for the new EU-wide framework, it also presents some flaws that must be critically addressed by the EU legislator, namely, the lack of clear guidance for businesses on the elaboration of a 'vigilance plan', 200 and the difficult burden on victims to show the causal link between the absence (or inadequacy) of the plan and the harm suffered. ${ }^{201}$

While addressing these challenges, the EU has the unique opportunity to promote a shared understanding of the human rights and environmental law principles that underpin due diligence, including in relation to climate change, going beyond the element of disclosure and requiring full integration of climate due diligence across business policies and processes. ${ }^{202}$ While HRDD remains an open-ended standard, its main elements should be clarified in law and possibly further explained in separate guidance documents. It should be made explicit that climate due diligence constitutes an inherent dimension of the standard of conduct required under the new legislation, and that its constitutive components reflect the structure of HRDD articulated in the UNGPs. Accompanying guidance documents could draw from a rich pool of sources to elaborate a shared definition of climate due diligence and clarify its link to HRDD. Such sources include not only the UNGPs, the OECD Guidelines, and the work of experts such as the IBA Task Force, but also the growing examples of case law in this field.

\section{Conclusions}

This article contributes to existing literature in the field of business and human rights, some of which has addressed the climate change dimension, ${ }^{203}$ by proposing a

\footnotetext{
198 EC, note 122, 225-227.

199 Ibid, 231; Angelica Dziedzic et al, 'Towards EU Legislation on Human Rights Due Diligence Case Study of the Garment and Textile Sector', HEC Paris Research Paper No. LAW-2017-1207 (2017) 11-15, https://papers.ssrn.com/ sol3/papers.cfm?abstract_id=2976330\&download=yes (accessed 18 May 2020).

200 Assessments of the first published plans highlight their shortcomings. ActionAid et al, 'The Law on Duty of Vigilance of Parent and Outsourcing Companies - Year 1: Companies Must Do Better' (2019), https:// corporatejustice.org/2019_collective_report__duty_of_vigilance_year_1.pdf (accessed 18 May 2020); EDH, 'Application of the Law on the Duty of Vigilance' (2019) 4, https://www.e-dh.org/userfiles/Etude\%20plans\%20de\% 20vigilance\%202019\%20-\%20VEN.pdf (accessed 18 May 2020); Shift, 'Human Rights Reporting in France' (2019) 10, https://www.shiftproject.org/media/resources/docs/Shift_HumanRightsReportingInFrance_Part2_vNov25.pdf (accessed 22 May 2020).

201 Bjorn Fasterling, 'Vigilance or Compliance? On the New French "Vigilance" Law' (2017), https:// bhr.stern.nyu.edu/blogs/french-vigiliance-law (accessed 18 May 2020).

202 A number of NGOs and international organizations have put in place guidelines to help businesses navigate various aspects of human rights due diligence, e.g., EC, 'Guidelines on Reporting Climate-Related Information' (2019); Sherpa, 'Vigilance Plans Reference Guidance' (2019).

203 See, for example, Meinhard Doelle and Sara L Seck, 'Loss and Damage from Climate Change: A Maturing Concept in Climate Law?' (2019) Climate Policy 1752; Stephen Humphreys (ed), Human Rights and Climate Change
} 
conceptualization of the consolidating concept of climate due diligence based on emerging climate change litigation, as well as on a holistic interpretation of the HRDD notion enunciated in the UNGPs. It clarifies that climate due diligence is a necessary dimension of HRDD as a standard of conduct, as well as a component of HRDD as a business process. It argues that nothing prevents a holistic interpretation of HRDD under the UNGPs based on all relevant norms of international law, and that such a holistic approach, combining mutually reinforcing principles of international human rights law, environmental law and climate law, actually constitutes the most coherent in the light of the stated aims of the UNGPs' normative framework. The proposed approach has the power to contribute to the consolidation of a coherent system of different but interrelated obligations for public and private actors in which crucial governance gaps can be bridged, particularly in relation to the scope and attribution of climate change-related responsibilities and to remedies for affected individuals and populations.

Most examples of climate change-related lawsuits initiated against corporations and states, some of which are successful, highlight that corporations are increasingly expected to take action in the two main areas: risk mitigation, which for some corporations might entail a significant reduction of emissions, and integration, which requires incorporating climate impacts across HRDD processes. Given the growing number of lawsuits, regulatory developments such as the upcoming EU-wide rules on human rights and environmental due diligence, as well as the increased attention of investors towards climate-related risks, corporations failing to take adequate action are exposed to legal, reputational and financial consequences.

This article builds on the UNGPs' articulation of HRDD as a business process to enucleate the main features of climate due diligence, arguing that all corporations, regardless of the size and sector, are required to assess their 'climate risk' as part of their human rights and environmental risk assessment. In doing so, they are required to take into account not only the level of their emissions, but also the climate impacts linked to them by their business relationships (e.g., corporations in their investment portfolio or supply chains). An integrated approach to risk assessment should consider not only the level of GHG emissions of a corporation and its affiliates, but also, more at large, the climate-related vulnerabilities of territories and communities, especially when the corporation's operations impact on local natural resources. The outcome of risk assessment will determine the type and complexity of the climate due diligence process, and has to be communicated externally. Big emitters accused of failing to

\footnotetext{
(Cambridge: Cambridge University Press, 2009), in particular chapter 4 by Newell; Olawuyi, note 126; Ottavio Quirico and Mouloud Boumghar (eds), Climate Change and Human Rights: An International and Comparative Law Perspective (Oxon: Routledge, 2015), in particular chapter 3 by Riddell and chapter 18 by Lambooy and Palm; Savaresi and Hartmann, note 35; Seck, note 162; Sara L Seck, 'Climate Change and the Human Rights Responsibilities of Business Enterprises' in David Ismangil, Karen van der Schaaf and Lars van Troost (eds), Climate Change, Justice and Human Rights (Amnesty International Netherlands, 2020), https://digitalcommons.schulichlaw.dal.ca/cgi/ viewcontent.cgi? article=1479\&context=scholarly_works (accessed 10 September 2020); Jaap Spier, 'The Principles on Climate Obligations of Enterprises: An Attempt to Give Teeth to the Universally Adopted View That We Must Keep Global Warming Below an Increase of Two Degrees Celsius' (2018) 23:2 Uniform Law Review 319; Kristian Høyer Toft, 'Climate Change as a Business and Human Rights Issue - A Proposal for a Moral Typology' (2019) 5:1 Business and Human Rights Journal 1; Samvel Varvastian and Felicity Kalunga, 'Transnational Corporate Liability for Environmental Damage and Climate Change: Reassessing Access to Justice after Vedanta v Lungowe’ (2020) 9:2 Transnational Environmental Law 323.
} 
honestly communicate their climate impacts are currently facing litigation in several jurisdictions. Climate due diligence might entail exercising leverage over the corporation's business affiliates and, in extreme cases, pulling out from projects and investments whose climate-related impacts cannot be mitigated. Corporations can be best prepared for any upcoming legal and judicial developments by working on risk management and integration making full use of available guidance. 